\title{
漢方保険診療所における柴胡剂の使用状況
}

\author{
中 村 久美子*，田中一 郎* \\ 山田光凮**
}

\section{Research into the Application of Saiko-zai, Ethial Kampo \\ Drugs Contained Bupleuri Radix in Our Kampo Clinic}

\author{
Kumiko NAKAMURA*, Ichiro TANAKA* \\ and Terutane YAMADA**
}

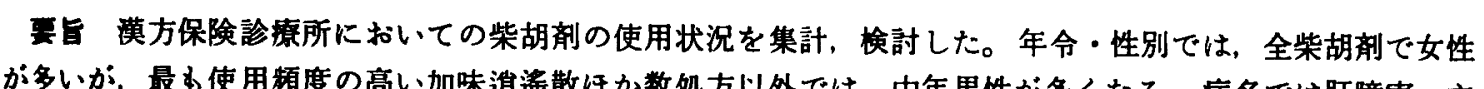
が多いが, 最も使用頻度の高い加味逍遙散ほか数処方以外では, 中年男性が多くなる。病名では肝障害, 主 訴では疲労倦总が多いといら結果が得られた。

\section{はじめに}

中国に起源をるつ漠方医学を用いる東洋の諸国の 中で，日本は柴胡を含む処方を用いることが多いと いわれる。しかし，どのような処方か，どのように 用いられているかを明らかにしたものは少ない。当 診港所は, 健保適用の漢方専門診療所として出発し てから 2 年余が释過した。そこで，柴胡を含むいく つかの処方について，使用状況を集計し，検討して みた。

\section{対魚と方法}

対象は昭和56年12月 1 日〜昭和58年11月30日まで の 2 年間に当診療所を受診した患者 12,934 人のらち 柴胡郕22処方（ここで柴胡剤とは，柴胡を含んた広 い意味のるのとする）を使用した患者 2,766人（21 4\%)である。今回は，この22処方について，(1)年 令・性別の分布, (2)病名, 上位20疾患について, (3) 主訴, 上位20主訴について, 当診療所の計算機シス テムを利用し，集計した。なお，処方においては， 合方されて処方されたものは，それぞれ別に数えて
いる。

\section{䊅果と考宾}

(1)年令・性別では，图 1の1)5)13）に示す加味逍 遙散, 十味敗毒湯, 乙字湯の 3 処方を除いては, 全 体的に男性, 特に中年層が多い。一方, 図 1 最後に 示されるよ5に全柴胡剤については，女性が多くな るが、これは, 加味逍遥散の使用頻度が高いことに よるものと考えられる。

(2)病名としては，表 1 のごとく，全体としては， 肝障害, 高血圧, 胃腸障害, 呼吸器疾患が多いとい える。

(3)主訴としては，表 2 のごとく，疲労侥急，咳， 肩凝りが多いといえる。

\section{まとめ}

今回, 我々は, 柴胡剤に怙ける(1)年令・性別, (2) 病名, (3)主訴との対応を検討した。ここで, 腹証な どの対応を検討した。ここで、腹証などの他覚所見 は，計算機システムへの入力が不充分であったた め，今回は集計の対象としなかった。さらに臨床的

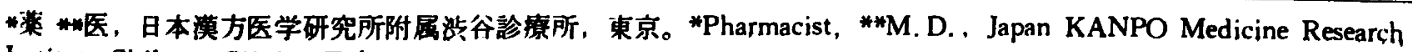
Institute Shibuya Clinic, Tokyo. 
に最も重要と思われる処方の有用性についても，な お，結論が得られていない。しかし，一次資料とし ての価値は十分有るものと確信している。今後の方 針としては，これらの知見にもとづき，計画をた
て、データを集積し，有用性を評価する前向きの研 究へと向からべきであろう。

（1984年 2 月22日受付） 
1)加味遇遥政

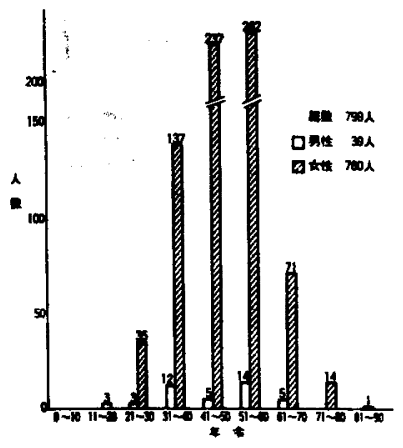

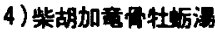

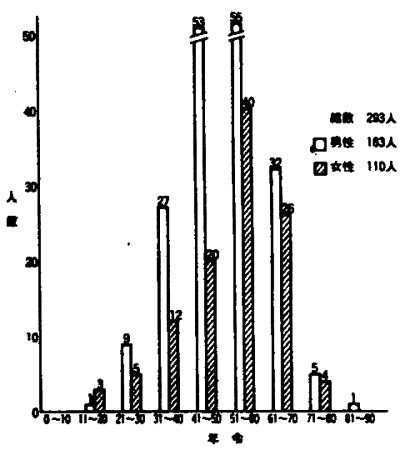

7)榑中並氢滔

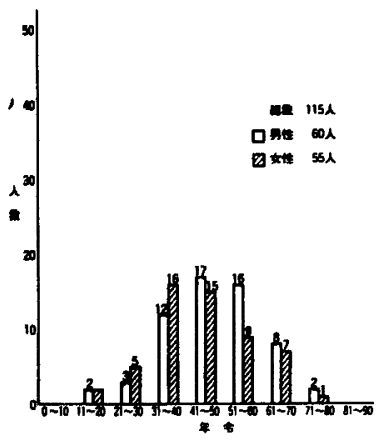

10)四迎粘

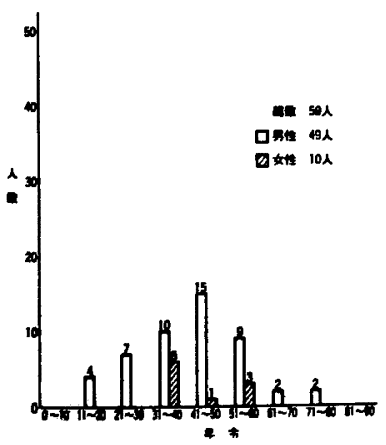

2)小柴胡温

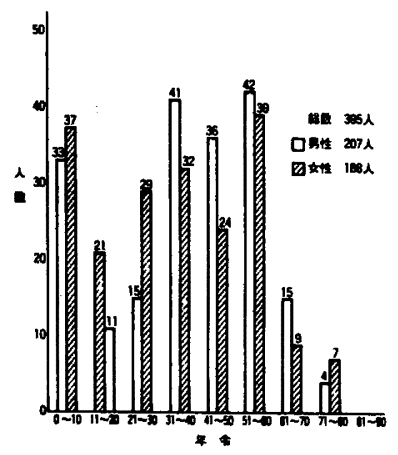

5)十味敗清

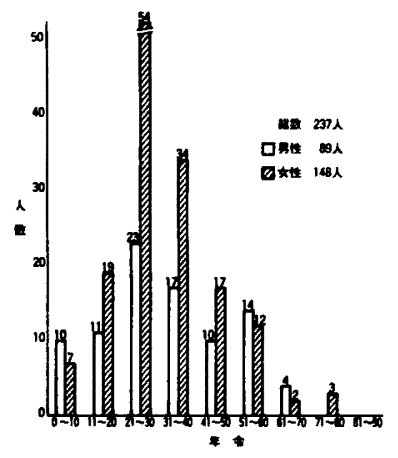

8)柴朴淐

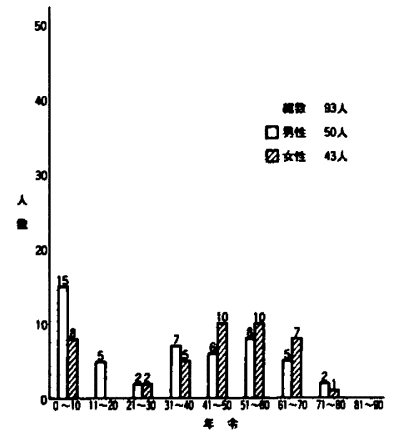

11)柴节清

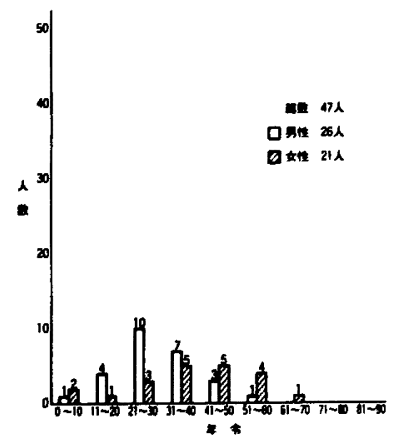

3) 柴胡桂枝淐

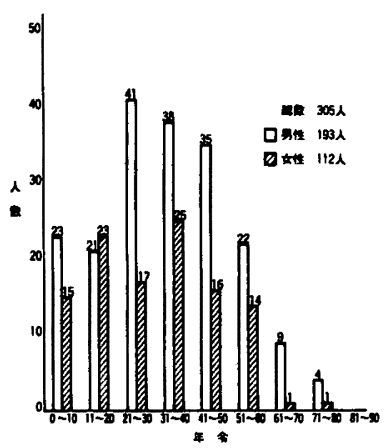

6)大柴胡湟

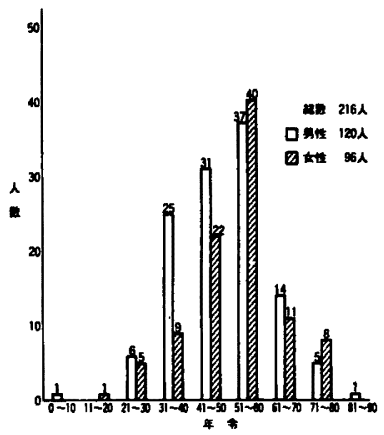

9）柴胡桂枝軚盖渴

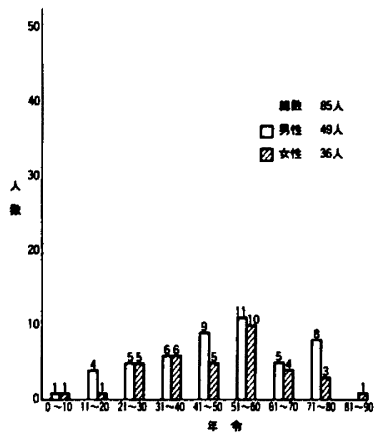

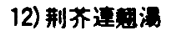

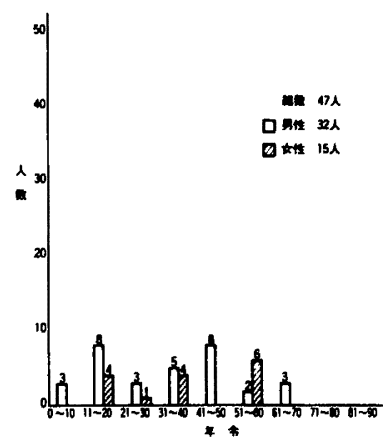


13)乙字

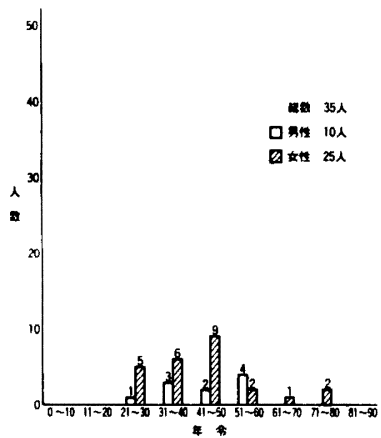

16) 滋除至宝海

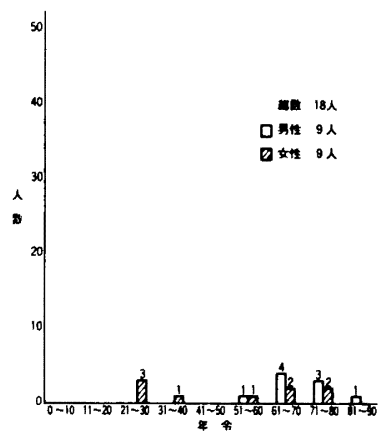

19)抑肝散加陳皮半亘
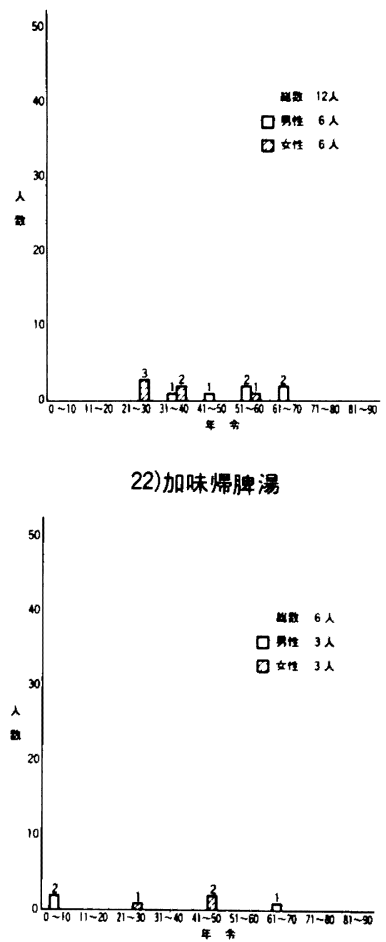

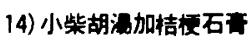

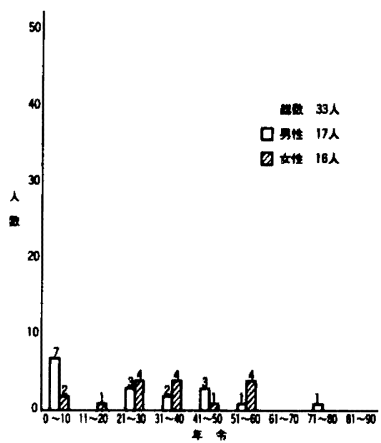

17) 柴胡清肝晹

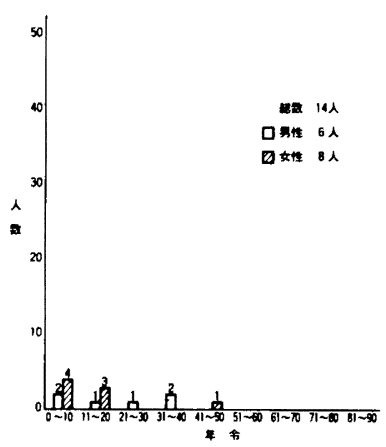

20) 抑 肝散

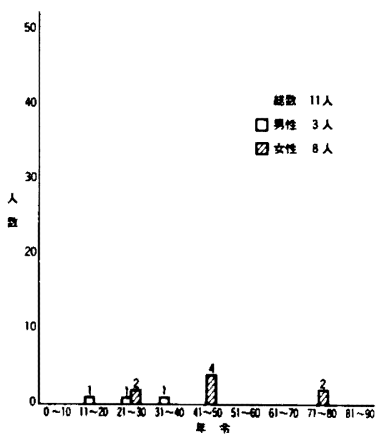

全柴胡剤

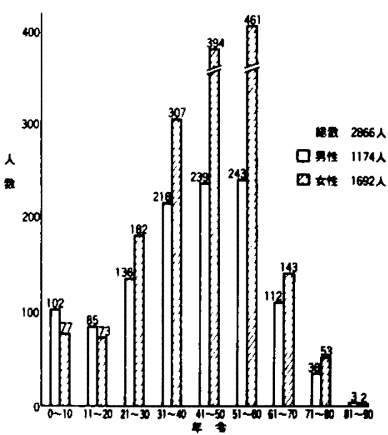

図1年令・性別分布
15)竹姑温䏣泊

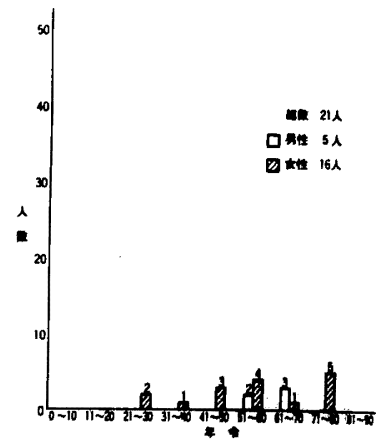

18)神秘酒

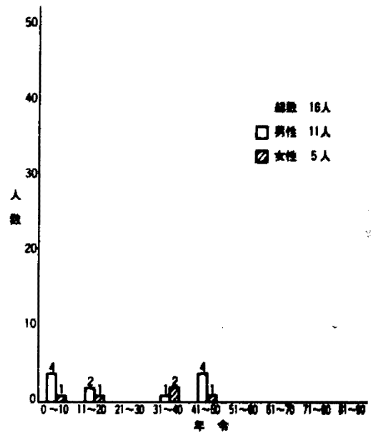

21)柴陥 滔

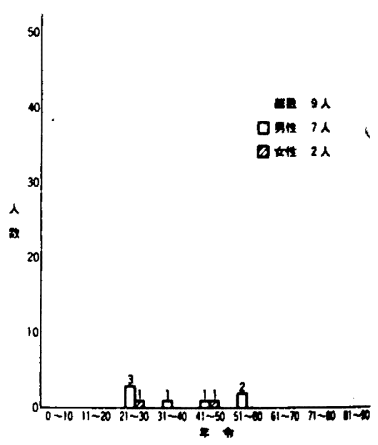




\section{4) 柴胡桂枝湯}

\begin{tabular}{|c|c|c|}
\hline 硯位 & 病 & 患者数 \\
\hline 1 & 慢 性 胃 炎 & 23 \\
\hline 2 & 胃＼cjkstart溃 & 22 \\
\hline " & 慢 性 肝 炎 & 22 \\
\hline 4 & 肝機能障害 & 21 \\
\hline 5 & 十二指腸潰䁑 & 16 \\
\hline 6 & 感 & 15 \\
\hline " & 夜 尿 & 15 \\
\hline 8 & 胆＼cjkstart石 & 14 \\
\hline 9 & 慢性気管支炎 & 13 \\
\hline 10 & アレルギー性尝炎 & 11 \\
\hline 11 & 胆 の う 炎 & 0 \\
\hline 12 & 慢性胃腸 炎 & 8 \\
\hline " & 湿 & 8 \\
\hline 14 & 急性気管支炎 & 7 \\
\hline " & 胃 下 垂 症 & 7 \\
\hline 16 & 神＼cjkstart経 & 6 \\
\hline$"$ & 急 - 慢性炎 & 6 \\
\hline " & 票 麻 疹 & 6 \\
\hline 19 & 気管支喘息 & 5 \\
\hline " & 急 性 胃 炎 & 5 \\
\hline$"$ & 胃アトニー症 & 5 \\
\hline$"$ & 慢 性 腎 炎 & 5 \\
\hline " & 貞＼cjkstart血 & 5 \\
\hline " & $\tau h$ 力 & 5 \\
\hline & そ の & 187 \\
\hline & 合 計 & 446 \\
\hline
\end{tabular}

5）十味敗毒湯

\begin{tabular}{|c|c|c|c|c|}
\hline 順位 & 病 & & 名 & 患者数 \\
\hline 1 & 湿 & & 疹 & 94 \\
\hline 2 & 薄 & 麻 & 疹 & 57 \\
\hline
\end{tabular}

\begin{tabular}{|l|lll|l|}
\hline 3 & に & $き$ & $\mho ゙$ & 20 \\
\hline 4 & \multicolumn{1}{|c|}{} & \\
\hline
\end{tabular}

\begin{tabular}{|r|l|r|}
\hline 4 & アトピー性皮的炎 & 14 \\
\hline 5 & アレルギー性算炎 & 13 \\
\hline 6 & 常 \\
\hline
\end{tabular}

\begin{tabular}{|l|ll|}
\hline 6 & 常 習 便 秘 11 \\
\hline 7 & 訮 \\
\hline
\end{tabular}

\begin{tabular}{|l|l|l|}
\hline 7 & 肝機能障害 & 8 \\
\hline 8
\end{tabular}

\begin{tabular}{|l|l|l|}
\hline 8 & 慢 性 胃 炎 & 6 \\
\hline 9
\end{tabular}

\begin{tabular}{|c|c|}
\hline 9 & 気管支喘息 \\
\hline
\end{tabular}

" 1 腎機能障害 4

\begin{tabular}{|l|ll|r|}
\hline " 貧 血 症 & 4 \\
\hline
\end{tabular}

12 アレルギー性皮底 炎 3

\begin{tabular}{|l|l|}
\hline$\prime$ & 皮症症症 3 \\
\hline
\end{tabular}

\begin{tabular}{|l|l|l|}
\hline 14 & 高 血 圧 症 & 2 \\
\hline
\end{tabular}

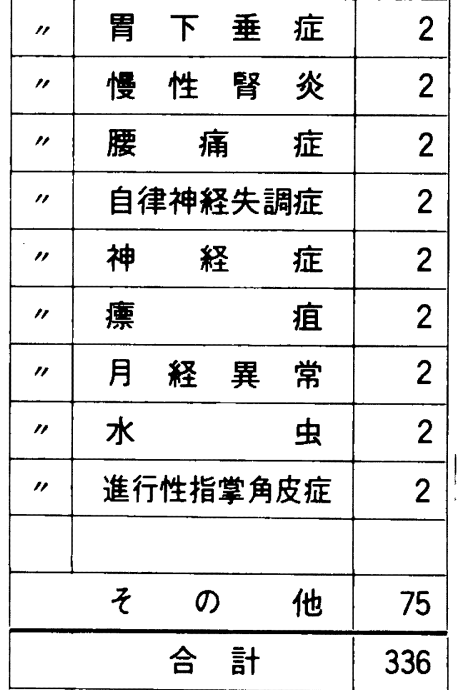

6）大柴胡湯

順位 病 名 患都

\begin{tabular}{|l|lll|r|}
\hline 1 & 高 & 血 & 症 & 74 \\
\hline 2 & 症 & 石 & 症 & 26 \\
\hline
\end{tabular}

\begin{tabular}{|c|c|}
\hline 2 & 胆 石 症 \\
\hline 3 & 慢 性 肝 炎 \\
\hline
\end{tabular}

\begin{tabular}{|c|c|c|c|}
\hline 4 & 糖 & $\bar{R}$ & \\
\hline
\end{tabular}

\begin{tabular}{|r|rrr|r|}
\hline 5 & 肥 & 満 & 症 & 18 \\
\hline 6 & 篦 & & & \\
\hline
\end{tabular}

\begin{tabular}{|l|l|r|}
\hline 6 & 常 習 便 秘 & 14 \\
\hline 7 & 肝 機能障害 & 10 \\
\hline
\end{tabular}

8 気管支喘息 9

\begin{tabular}{|c|c|c|c|}
\hline 9 & 湿 & 疹 & 8 \\
\hline 10 & 心 肥 & 大 & 6 \\
\hline
\end{tabular}

11 腎機能障害 5

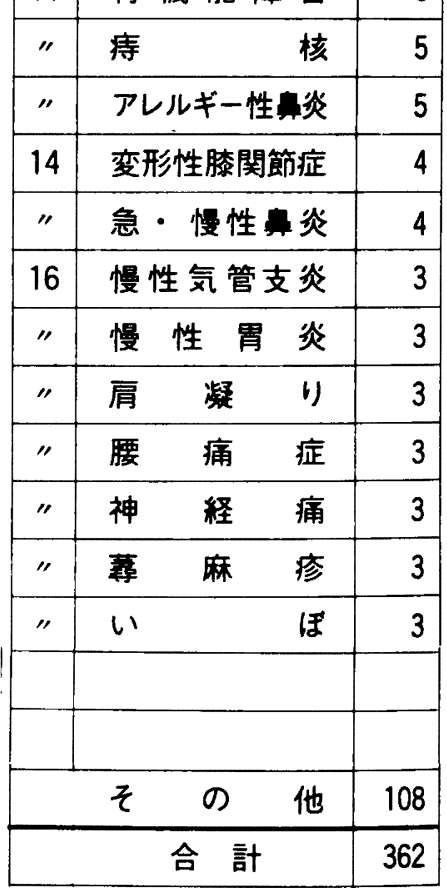


7) 補中益気湯

\begin{tabular}{|c|c|c|}
\hline 唄位 & 病 & 患者数 \\
\hline 1 & 慢 性 肝 炎 & 21 \\
\hline 2 & 低 血 圧 症 & 9 \\
\hline " & 慢 性 胃 炎 & 9 \\
\hline 4 & 胃 下 垂 症 & 8 \\
\hline " & 慢性 胃 腸 炎 & 8 \\
\hline 6 & 高 血 圧 症 & 7 \\
\hline " & 糖 尿 病 & 7 \\
\hline 8 & 感 & 6 \\
\hline$"$ & 肝 機 能 障 害 & 6 \\
\hline " & 贫 血 症 & 6 \\
\hline 11 & 腎樴 能障害 & 4 \\
\hline$"$ & 自律神経失調症 & 4 \\
\hline 13 & 肝 硬 変 & 3 \\
\hline " & 庤 万 & 3 \\
\hline 15 & 不 整 脈 & 2 \\
\hline " & 食 欲 不 振 & 2 \\
\hline$"$ & 胃アトニー症 & 2 \\
\hline " & 常 習 便 秘 & 2 \\
\hline$"$ & 慢 性 腎 炎 & 2 \\
\hline$"$ & 全 身 僚 怠 & 2 \\
\hline " & 腰 痛 症 & 2 \\
\hline " & 椎間板ヘルニア & 2 \\
\hline " & ヘ $ル=ア$ & 2 \\
\hline " & 核 & 2 \\
\hline$"$ & 副 & 2 \\
\hline$"$ & 湿 & 2 \\
\hline & そ の 他 & 62 \\
\hline & 合 計 & \\
\hline
\end{tabular}

8) 柴朴湯

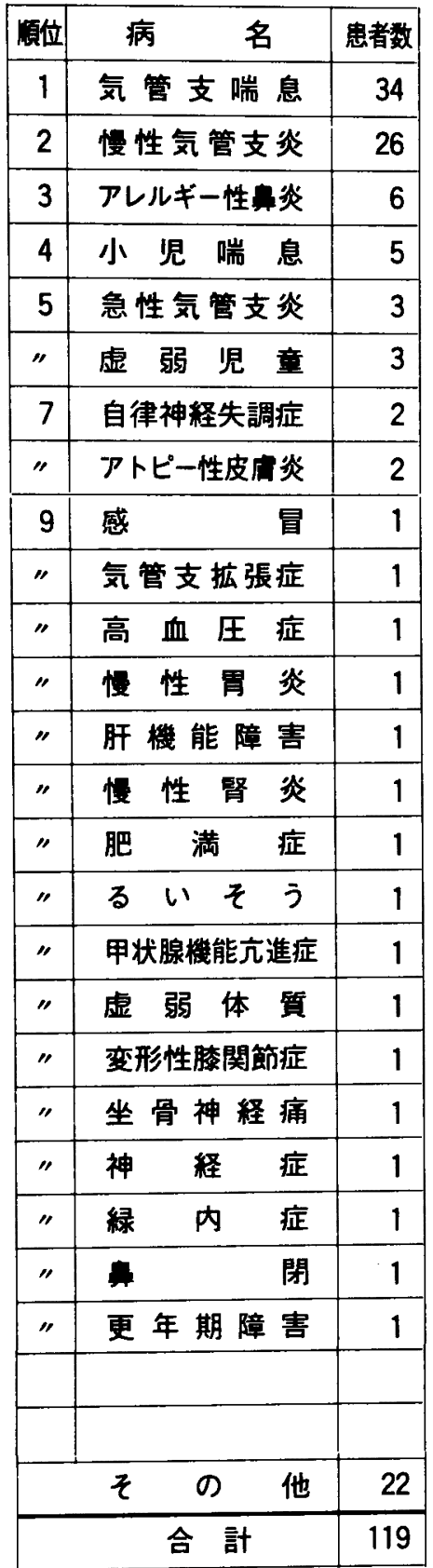

9）柴胡桂枝乾姜湯

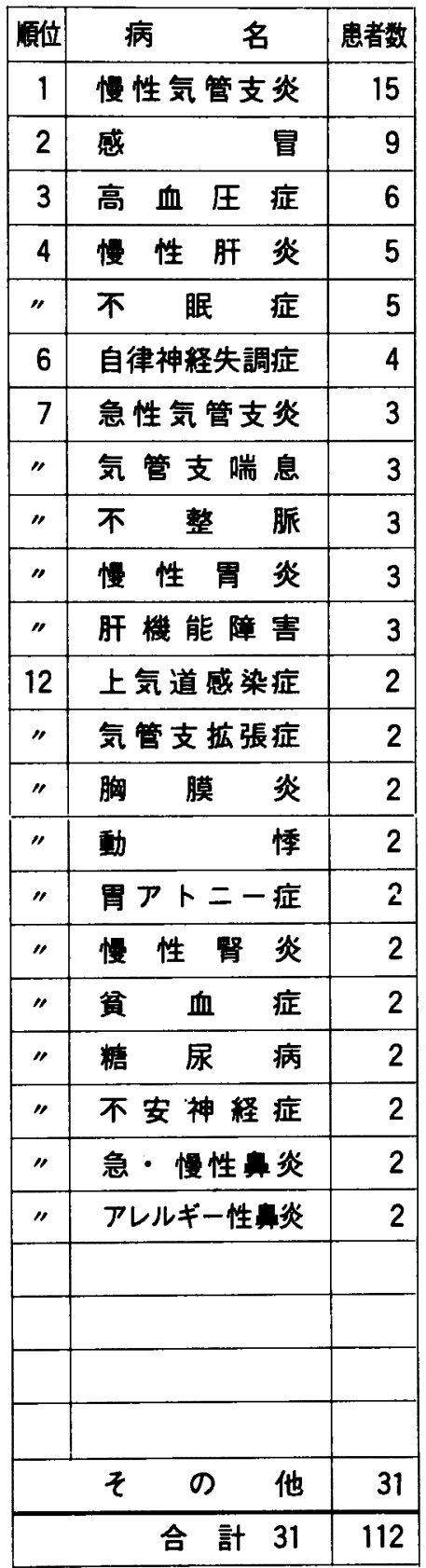


10）四逆散

\begin{tabular}{|c|c|c|}
\hline 䚊位 & 病 & 患者数 \\
\hline 1 & アレルギー性酌炎 & 6 \\
\hline 2 & 湿疹 & 5 \\
\hline 3 & 神経 症 & 4 \\
\hline 4 & 高 血 圧 症 & 3 \\
\hline " & 胆 石 症 & 3 \\
\hline$"$ & 胆 の う 炎 & 3 \\
\hline$"$ & 肝 機 能 障 害 & 3 \\
\hline$"$ & 急 - 慢性筑 & 3 \\
\hline 9 & 急 性 胃 炎 & 2 \\
\hline$"$ & 糖 尿 症 & 2 \\
\hline " & 椎間板ヘルニア & 2 \\
\hline " & 副 腔 炎 & 2 \\
\hline$"$ & 乾应 & 2 \\
\hline " & 腰 痛 症 & 2 \\
\hline & & \\
\hline & & \\
\hline & そ & 36 \\
\hline & 合 計 & 82 \\
\hline
\end{tabular}

11）柴苓湯

\begin{tabular}{|c|c|c|}
\hline 順位 & 病 & 患者数 \\
\hline 1 & 慢 性 腎 炎 & 19 \\
\hline 2 & 高 血 圧 症 & 3 \\
\hline " & 慢 性 胃 炎 & 3 \\
\hline 4 & 下 痢 症 & 1 \\
\hline " & 急 性 肝 炎 & 1 \\
\hline$"$ & 慢性胃腸 炎 & 1 \\
\hline " & 肝機能障害 & 1 \\
\hline " & ネフロ ゼ & 1 \\
\hline " & 督＼cjkstart不 & 1 \\
\hline " & 虚 弱 児 童 & 1 \\
\hline$"$ & 月 経 異 常 & 1 \\
\hline " & 子 宮 觔 腫 & 1 \\
\hline " & 莠麻疹 & 1 \\
\hline " & 湿 & 1 \\
\hline " & に き び & 1 \\
\hline " & アトピー性皮栭炎 & 1 \\
\hline " & $S \quad L$ & 1 \\
\hline$"$ & 膠原 & 1 \\
\hline & そ の & 22 \\
\hline & 合 計 & 62 \\
\hline
\end{tabular}

12）荆芥連趣湯

\begin{tabular}{|c|c|c|}
\hline 順位 & 病 & 患者数 \\
\hline 1 & 湿 & 10 \\
\hline 2 & 副 腔 炎 & 9 \\
\hline 3 & 急 - 慢性炎 & 5 \\
\hline " & アトピー性皮虎炎 & 5 \\
\hline 5 & アレルギー性党 & 3 \\
\hline 6 & 白 内 障 & 2 \\
\hline " & 扁桃肥大症 & 2 \\
\hline$"$ & 前立腺肥大症 & 2 \\
\hline 9 & 寄 生 虫 症 & 1 \\
\hline " & 慢性気管支炎 & 1 \\
\hline " & 気管支喘息 & 1 \\
\hline$"$ & 高 血 圧 症 & 1 \\
\hline " & 慢 性 肝 炎 & 1 \\
\hline$"$ & 肝機能障害 & 1 \\
\hline$"$ & 急・慢性中耳炎 & 1 \\
\hline 9 & び & 1 \\
\hline " & わ き か & 1 \\
\hline & の & 14 \\
\hline & 合 計 & 61 \\
\hline
\end{tabular}

〔10）の患者数 1 人は省略し

その他に入れた。 
13）乙字湯

\begin{tabular}{|c|c|c|}
\hline 醇位 & 病 & 息者数 \\
\hline 1 & 庤 & 21 \\
\hline 2 & 庤 万 & 5 \\
\hline 3 & 肛門 - 直閙脱出 & 4 \\
\hline 4 & 慢 性 胃 炎 & 3 \\
\hline " & 常 習 便 秘 & 3 \\
\hline 6 & 惨胜 娦 & 2 \\
\hline$"$ & 自律神経失調症 & 2 \\
\hline " & 急 - 慢性资 & 2 \\
\hline$"$ & 疹 & 2 \\
\hline " & 膀 肤 炎 & 2 \\
\hline 11 & 感 & 1 \\
\hline$"$ & 高 血 压 症 & 1 \\
\hline " & 胃アトニー症 & 1 \\
\hline$"$ & 悓 性 腸 资 & 1 \\
\hline " & 慢性胃腸 炎 & 1 \\
\hline$"$ & 肝 機 能 障 害 & 1 \\
\hline$"$ & 变形性背椎症 & 1 \\
\hline$"$ & 不 眠 症 & 1 \\
\hline " & $\wedge ル=\boldsymbol{P}$ & 1 \\
\hline$"$ & 副 腔 资 & 1 \\
\hline$"$ & 月 経 異 常 & 1 \\
\hline " & 子 宮 筋 腫 & 1 \\
\hline$"$ & い & 1 \\
\hline & そ の 他 & 6 \\
\hline & 合 計 & 65 \\
\hline
\end{tabular}

14）小柴胡湯加桔梗石票

\begin{tabular}{|c|c|c|}
\hline 谼位 & 病 & 患者数 \\
\hline 1 & 急・惊性中耳炎 & 5 \\
\hline " & 急性扁桃腺炎 & 5 \\
\hline 3 & 慢性気管支炎 & 4 \\
\hline 4 & 嘪 & 3 \\
\hline$"$ & 扁桃肥大症 & 3 \\
\hline 6 & 上気道感染症 & 2 \\
\hline " & 気管支喘息 & 2 \\
\hline " & 虚 弱 児 童 & 2 \\
\hline$"$ & 急 - 慢性资 & 2 \\
\hline 10 & 高 血 圧 症 & 1 \\
\hline " & 食道神経症 & 1 \\
\hline " & 慢 性 胃 炎 & 1 \\
\hline " & 慢 性 肝 炎 & 1 \\
\hline " & 胆 石 症 & 1 \\
\hline " & 慢性胃腸 炎 & 1 \\
\hline$"$ & $\begin{array}{lll}\text { 肥 満 症 } \\
\end{array}$ & 1 \\
\hline " & 肩凝 り & 1 \\
\hline$"$ & 常 習 頭 痛 & 1 \\
\hline$"$ & 自律神経失調症 & 1 \\
\hline " & 㸶 頭 炎 & 1 \\
\hline "' & 月 経 異 常 & 1 \\
\hline " & 月経困 難 症 & 1 \\
\hline " & 湿 & 1 \\
\hline & そ $\quad$ の & 8 \\
\hline & 合 計 & 50 \\
\hline
\end{tabular}

15）竹筎温胆湯

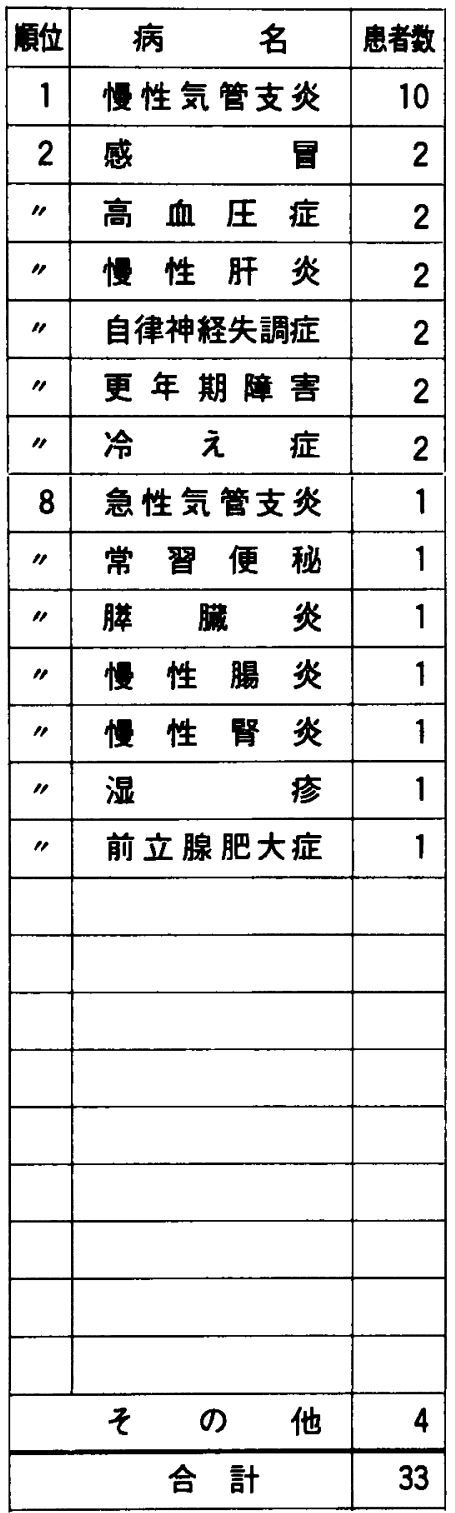


16）滋陰至宝湯

\begin{tabular}{|c|c|c|}
\hline 䨄 & 病 & 患者数 \\
\hline 1 & 慢性気管支炎 & \\
\hline 2 & 気管支拡張症 & \\
\hline 3 & 懪 性 胃 炎 & 2 \\
\hline 4 & 気管支喘息 & 1 \\
\hline$"$ & 肺 結 核 & 1 \\
\hline " & $\begin{array}{lll}\text { 肺 } & \text { 氞 } \\
\end{array}$ & \\
\hline " & アレルギー性算炎 & 1 \\
\hline " & 不 姡 症 & 1 \\
\hline " & 冷 え 症 & 1 \\
\hline \multicolumn{2}{|r|}{ そ の 他 } & 4 \\
\hline & 合 計 & \\
\hline
\end{tabular}

17）柴胡清肝湯

\begin{tabular}{|c|c|c|}
\hline 碩位 & 病 & 患者数 \\
\hline 1 & アトピー性皮凬炎 & 9 \\
\hline 2 & 疹 & 2 \\
\hline 3 & 気管支喘息 & 1 \\
\hline " & 急 性 胃 炎 & 1 \\
\hline$"$ & 慢 性 胃 炎 & 1 \\
\hline " & 肥 満 症 & 1 \\
\hline$"$ & 不 眠 症 & 1 \\
\hline$"$ & 小 児 喘 息 & 1 \\
\hline$"$ & 急 - 慣性党炎 & 1 \\
\hline$"$ & 扁 桃 肥 大症 & 1 \\
\hline & 合 計 & 19 \\
\hline
\end{tabular}

18）神秘湯

\begin{tabular}{|c|c|c|}
\hline 碩位 & 病名 & 息者到 \\
\hline 1 & 気管支喘息 & 9 \\
\hline 2 & 慢性気管支炎 & 1 \\
\hline " & 慢 性 雷 炎 & 1 \\
\hline " & 虚 弱 児 童 & 1 \\
\hline " & アトピー性皮福炎 & 1 \\
\hline & & \\
\hline & & \\
\hline & & \\
\hline & z & 5 \\
\hline & 合 計 & 18 \\
\hline
\end{tabular}

19）抑肝散加陳皮半夏

\begin{tabular}{|c|c|c|}
\hline 唄位 & 病 & 患者数 \\
\hline 1 & 神 経 症 & 6 \\
\hline 2 & 慢 性 胃 炎 & 2 \\
\hline " & 自律神経失調症 & 2 \\
\hline 4 & 高 血 圧 症 & 1 \\
\hline " & 慢 性 腸 炎 & 1 \\
\hline " & 腎舌 炎 & 1 \\
\hline$"$ & パーキンソン症候群 & 1 \\
\hline " & 常 習 頭 痛 & 1 \\
\hline " & 脳卒中後遗症 & 1 \\
\hline$"$ & 带 & 1 \\
\hline " & 月 経 異 常 & 1 \\
\hline & $\xi \quad \sigma$ & 2 \\
\hline & 合 計 & 20 \\
\hline
\end{tabular}

20）抑肝散

\begin{tabular}{|c|c|c|}
\hline 顏位 & 病 & 患者数 \\
\hline 1 & パーキンソン症侯 群 & 3 \\
\hline 2 & 高 血 生 症 & 2 \\
\hline " & 更年 期 障害 & 2 \\
\hline 4 & 常 習 便 秘 & 1 \\
\hline " & 常 習 頭 痛 & 1 \\
\hline " & 自律神経失調症 & 1 \\
\hline " & 神経 症 & 1 \\
\hline " & 躁 うつ病 & 1 \\
\hline " & チック 病 & 1 \\
\hline " & アレルギー性筷 & 1 \\
\hline " & 卵 巣 機 能不全 & 1 \\
\hline & そ $\quad$ の 他 & 1 \\
\hline & 計 & 16 \\
\hline
\end{tabular}

21）柴陥湯

\begin{tabular}{|c|c|c|}
\hline 唄位 & 病 & 思者就 \\
\hline 1 & 慢性気管支炎 & 4 \\
\hline 2 & 急性気管支炎 & 2 \\
\hline " & 気管支喘息 & 2 \\
\hline 4 & 感 & 1 \\
\hline$"$ & 扁桃肥大症 & 1 \\
\hline & の & 2 \\
\hline & 合 計 & 12 \\
\hline
\end{tabular}

22）加味帰脾湯

\begin{tabular}{|c|c|c|}
\hline 票位 & 病 & atod \\
\hline 1 & 不安神释症 & \\
\hline " & 留巣機能不全 & 1 \\
\hline & 他 & \\
\hline & 合 計 & \\
\hline
\end{tabular}

(满名においては延へ人数を) 使用している。 
表 2 主訴・上位20疾患

1) 加味逍遥散

\begin{tabular}{|c|c|c|}
\hline 尌位 & 主 & 思者数 \\
\hline 1 & 肩凝 り & 50 \\
\hline 2 & 痛 & 47 \\
\hline 3 & 眠 & 27 \\
\hline " & 冷 & 27 \\
\hline 5 & 高 血 压 & 22 \\
\hline$"$ & 疲 労 倦 急 & 22 \\
\hline 7 & 秘 & 21 \\
\hline 8 & め ま $\quad$ 小 & 17 \\
\hline 9 & 発 & 16 \\
\hline " & 変色のある皮庙 & 16 \\
\hline " & 疲れやすい & 16 \\
\hline 12 & 安 & 14 \\
\hline 13 & 悸 & 13 \\
\hline$"$ & 痛 & 13 \\
\hline " & 疹 & 13 \\
\hline " & 関 節 痛 & 13 \\
\hline$"$ & 胃のもたれ & 13 \\
\hline 18 & の ほ せ & 12 \\
\hline$"$ & 不 定 愁 訴 & 12 \\
\hline$"$ & 重 & 12 \\
\hline & そ $\quad$ の 他 & 403 \\
\hline & 合 & 799 \\
\hline
\end{tabular}

2) 小柴胡湯

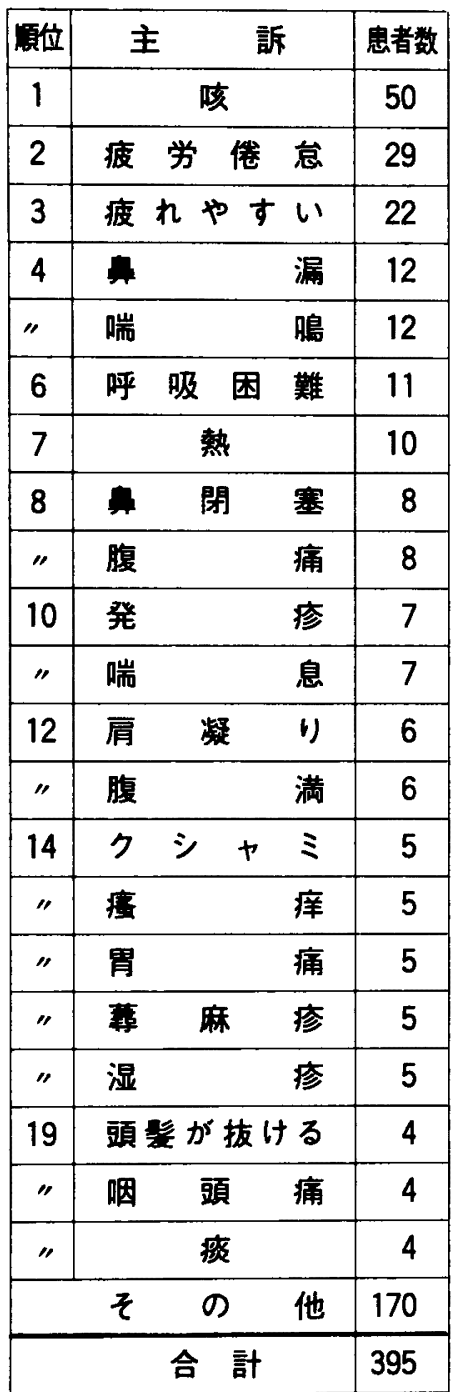

3）柴胡桂枝湯

\begin{tabular}{|c|c|c|c|}
\hline 順位 & 訴 & & 患者数 \\
\hline 1 & 胃 & 痛 & 36 \\
\hline 2 & 腹 & 痛 & 21 \\
\hline 3 & 頭 & 痛 & 10 \\
\hline " & \multicolumn{2}{|l|}{ 咳 } & 10 \\
\hline 5 & 閉 & 塞 & 8 \\
\hline " & 腹 & 満 & 8 \\
\hline 7 & 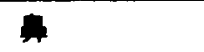 & 漏 & 7 \\
\hline$"$ & 排 尿 異 & 常 & 7 \\
\hline$"$ & 疲 労 倦 & 总 & 7 \\
\hline " & 夜＼cjkstart尿 & 症 & 7 \\
\hline 11 & 胃のもた & & 6 \\
\hline 12 & 肩＼cjkstart凝 & b) & 5 \\
\hline$"$ & 腰 & 痛 & 5 \\
\hline$"$ & 痙 & 鳘 & 5 \\
\hline 15 & めま & い & 4 \\
\hline " & $ク$ シ ャ & 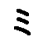 & 4 \\
\hline$"$ & 視 力 障 & 害 & 4 \\
\hline$"$ & 咽＼cjkstart頭 & 痛 & 4 \\
\hline$"$ & 熱 & & 4 \\
\hline$"$ & 背 & 痛 & 4 \\
\hline " & 疲 れ やす & & 4 \\
\hline & そ の & 他 & 135 \\
\hline & 合 計. & & 305 \\
\hline
\end{tabular}


4) 柴胡加竜骨牞蚛湯

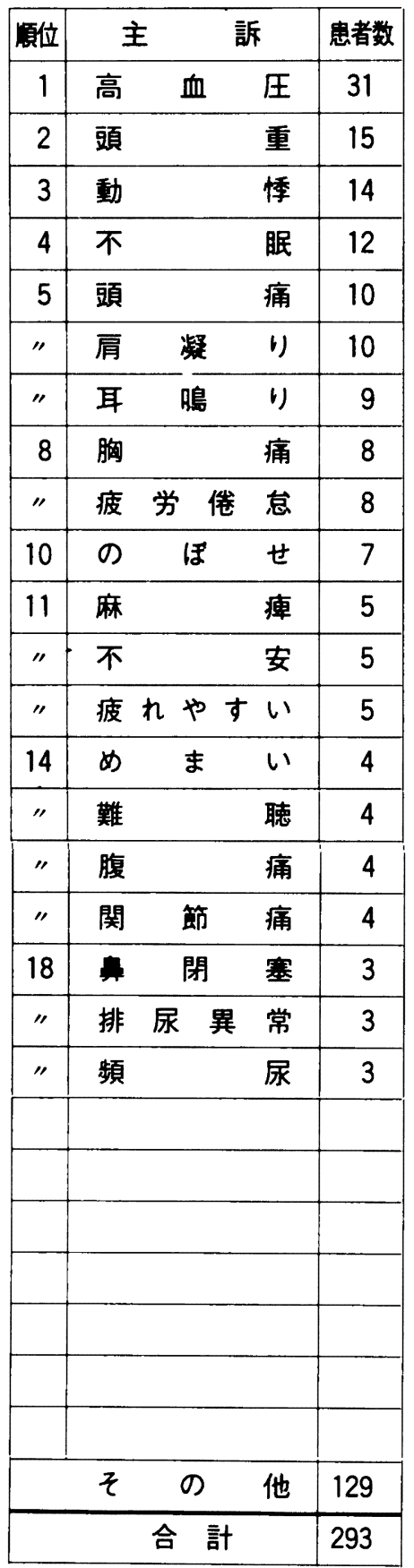

5 ）十味敗毒湯

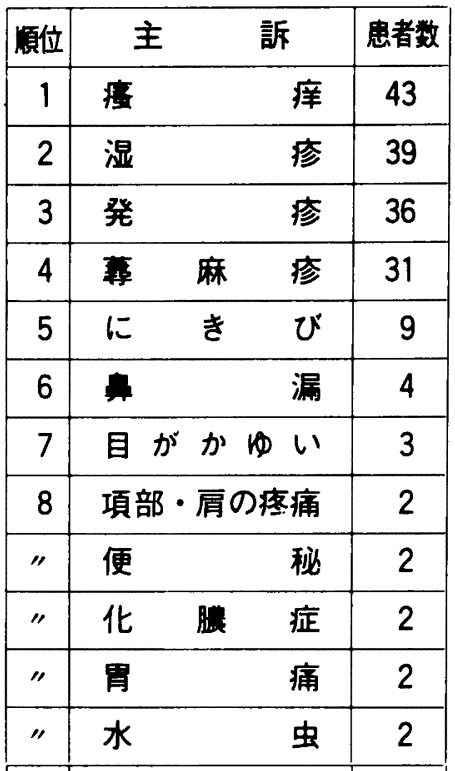

6）大柴胡湯

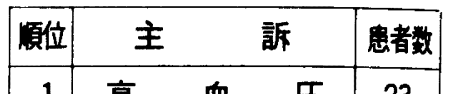
\begin{tabular}{|c|ccc|c|}
\hline 1 & 高 & 血 & 圧 & 23 \\
\hline 2 & 肩 & 凝 & り & 16 \\
\hline 3 & &
\end{tabular}

\begin{tabular}{|l|ll|l|}
\hline 3 & 腹 & 痛 & 11 \\
\hline 4 & 便 & 政 & 7 \\
\hline
\end{tabular}

\begin{tabular}{|c|cc|c|}
\hline 4 & 便 & 秘 & 7 \\
\hline 5 & 腰 & 痛 & 6 \\
\hline$"$ & 腹 & 満 & 6 \\
\hline
\end{tabular}

\begin{tabular}{|c|c|c|c|}
\hline I & 腹 & 満 & 6 \\
\hline$"$ & 関＼cjkstart節 & 痛 & 6 \\
\hline 8 & 上下肢の疼 & & 5 \\
\hline " & 疲 労 供 & & 5 \\
\hline " & 湿 & 疹 & 5 \\
\hline " & 肥 & 满 & 5 \\
\hline " & 瘦 & 痒 & 5 \\
\hline 13 & 咳 & & 4 \\
\hline$"$ & 呼 吸 困 & 難 & 4 \\
\hline$"$ & 疲れやす & & 4 \\
\hline 16 & 閉 & 塞 & 3 \\
\hline " & 手足のしび & & 3 \\
\hline$"$ & 胃 & 痛 & 3 \\
\hline 19 & 頭 & 痛 & 2 \\
\hline " & 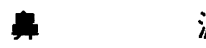 & 漏 & 2 \\
\hline$"$ & 項部・肩の疼秘 & & 2 \\
\hline " & 動 & 悸 & 2 \\
\hline " & 嗄 & 声 & 2 \\
\hline$"$ & 変色のある皮 & & 2 \\
\hline " & 浮 & 腫 & 2 \\
\hline " & 立 ちくら & み & 2 \\
\hline " & 喘 & 息 & 2 \\
\hline & そ の & 他 & 77 \\
\hline & 合 計 & & 216 \\
\hline
\end{tabular}


7) 補中益気湯

\begin{tabular}{|c|c|c|}
\hline 賈位 & 主 & 患者数 \\
\hline 1 & 疲 労 偻 急 & 33 \\
\hline 2 & 疲れやすい & 11 \\
\hline 3 & 痛 & 4 \\
\hline$"$ & 食不 振 & 4 \\
\hline " & 下 痢 & 4 \\
\hline 6 & 寿の事み，瘈み，脱肛 & 3 \\
\hline$"$ & 胃のもたれ & 3 \\
\hline " & 眼 精 疲 労 & 3 \\
\hline 9 & 胸痛 & 2 \\
\hline " & 婹痛 & 2 \\
\hline$"$ & 変色のある皮的 & 2 \\
\hline$"$ & 湿胗 & 2 \\
\hline$"$ & 凮邪をひきやむ & 2 \\
\hline & & \\
\hline & & \\
\hline & & \\
\hline & & \\
\hline & そ の & 40 \\
\hline & 合 計 & 115 \\
\hline
\end{tabular}

8）柴朴湯

\begin{tabular}{|c|c|c|}
\hline 醇位 & 主 & 患者数 \\
\hline 1 & 咳 & 24 \\
\hline 2 & 呼 吸 困 難 & 11 \\
\hline 3 & 喘 鳴 & 9 \\
\hline 4 & 喘 & 5 \\
\hline 5 & 漏 & 3 \\
\hline 6 & 悸 & 2 \\
\hline$"$ & 痛 & 2 \\
\hline$"$ & 痰 & 2 \\
\hline 9 & $ク$ シ & 1 \\
\hline " & 声 & 1 \\
\hline$"$ & 痛 & 1 \\
\hline " & 高血 圧 & 1 \\
\hline$"$ & if つ s & 1 \\
\hline$"$ & 関節 痛 & 1 \\
\hline " & 不 定 愁 訴 & 1 \\
\hline$"$ & 出 血 & 1 \\
\hline$"$ & 疲れやすい & 1 \\
\hline$"$ & 不整 脈 & 1 \\
\hline " & 風邪をひきやすい & 1 \\
\hline & そ $\quad$ 他 & 24 \\
\hline & 合 計 & 93 \\
\hline
\end{tabular}

9) 柴胡桂枝乾美湯

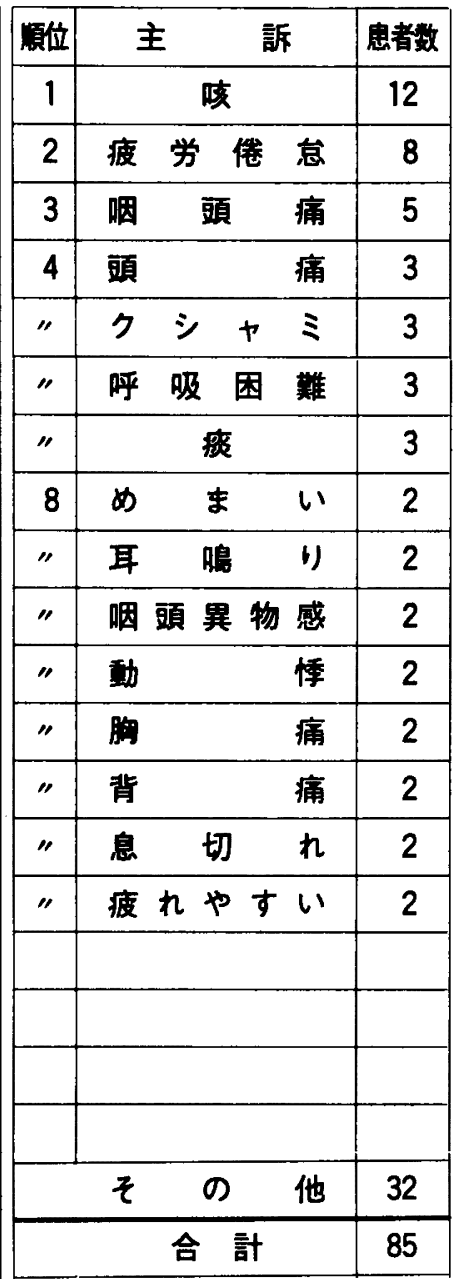


10）四逆散

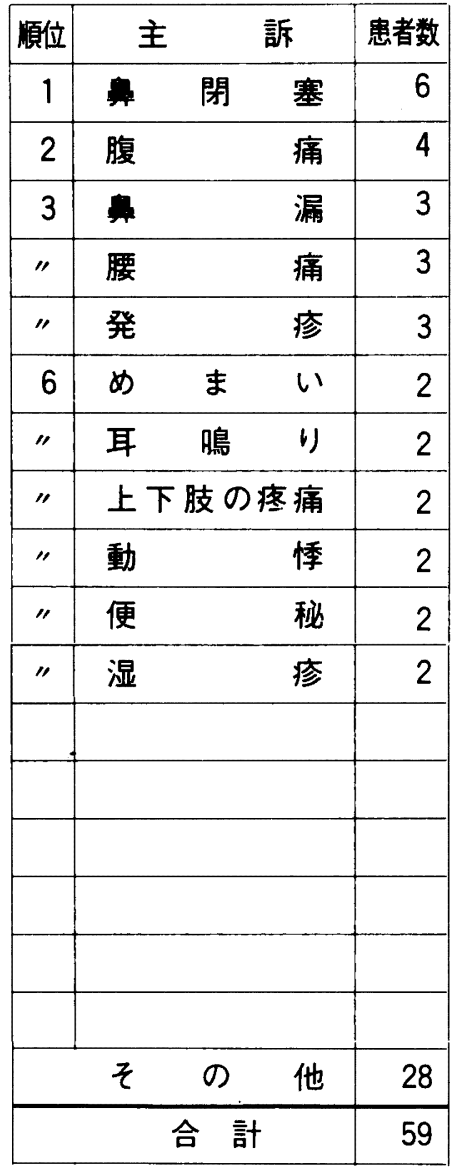

11）柴苓湯

\begin{tabular}{|c|c|c|}
\hline 頪位 & 主訴 & 患者 \\
\hline 1 & 疲 労 倦 & 9 \\
\hline 2 & タンパク & 5 \\
\hline 3 & 排 尿 異 & 3 \\
\hline 4 & 浮 & 2 \\
\hline " & 血 & 2 \\
\hline " & 疲れやす & 2 \\
\hline 7 & 肩凝 & 1 \\
\hline$"$ & 便 & 1 \\
\hline " & 腹 & 1 \\
\hline " & 高 血 E & 1 \\
\hline$"$ & 熱 & 1 \\
\hline " & 変色のある皮后 & 1 \\
\hline " & 胃のもた & 1 \\
\hline " & 下 腹 病 & 1 \\
\hline$"$ & 背 & 1 \\
\hline " & 頻 & 1 \\
\hline & 虚 弱 体 & 1 \\
\hline & その & 13 \\
\hline & 合 計 & 47 \\
\hline
\end{tabular}

12）荆芥連䞇湯

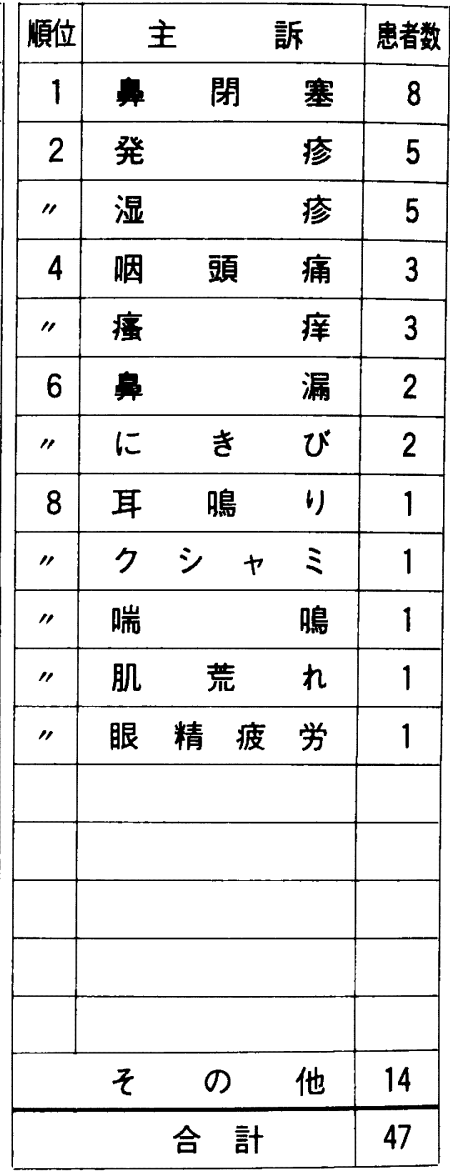


13）乙字湯

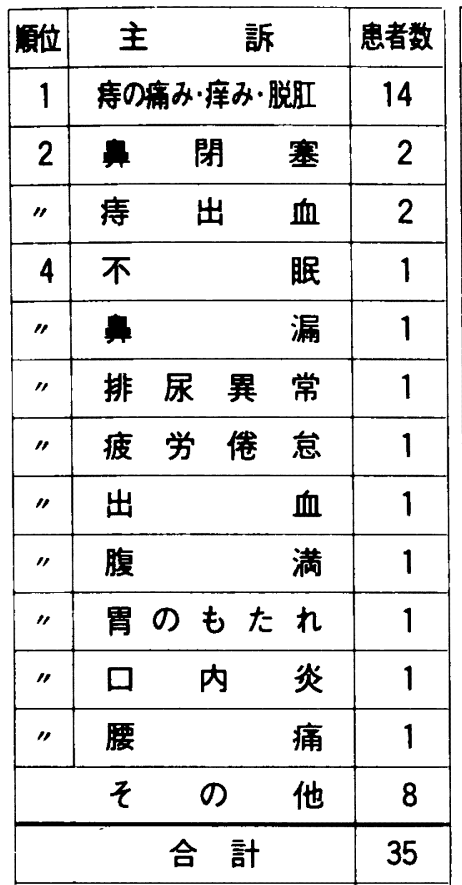

14）小柴胡湯加桔梗石亭

\begin{tabular}{|c|c|c|c|}
\hline 嶰立 & \multicolumn{2}{|l|}{ 主 } & \multirow{2}{*}{$\begin{array}{r}\text { 患者数 } \\
9\end{array}$} \\
\hline 1 & 咽 & 痛 & \\
\hline 2 & \multicolumn{2}{|l|}{ 咳 } & 4 \\
\hline$"$ & \multicolumn{2}{|l|}{ 熱 } & 4 \\
\hline 4 & \multicolumn{2}{|c|}{ 風邪をひきやすい } & 2 \\
\hline 5 & \multicolumn{2}{|l|}{ 頭 } & 1 \\
\hline$"$ & \multicolumn{2}{|l|}{ 庤 } & 1 \\
\hline$"$ & \multicolumn{2}{|c|}{ 咽 頭 異物 感 } & 1 \\
\hline$"$ & \multicolumn{2}{|c|}{ 肩凝 り } & 1 \\
\hline$"$ & \multicolumn{2}{|c|}{ 胸 や } & 1 \\
\hline$"$ & \multicolumn{2}{|c|}{ 胃のもたれ } & 1 \\
\hline$"$ & \multicolumn{2}{|c|}{ 喘 息 } & 1 \\
\hline$"$ & \multicolumn{2}{|c|}{ 疲れやすい } & 1 \\
\hline & \multicolumn{2}{|c|}{ そ の 他 } & 6 \\
\hline & \multicolumn{2}{|l|}{ 合 計 } & 33 \\
\hline
\end{tabular}

15）竹筎温胆湯

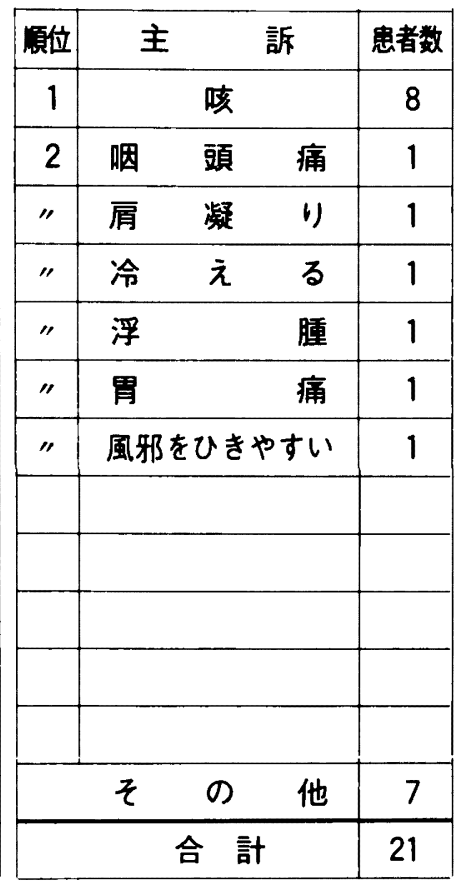

16）滋陰至宝湯

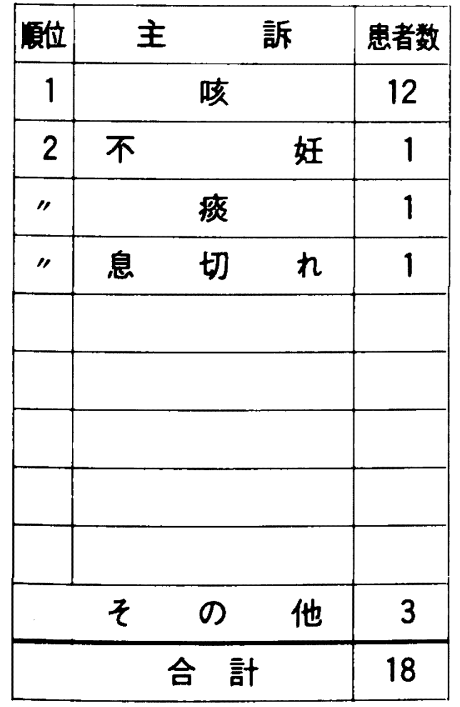

17）柴胡清肝湯

\begin{tabular}{|c|c|c|c|}
\hline 頱位 & \multicolumn{2}{|l|}{ 主訴 } & 患者数 \\
\hline 1 & 瘦 & 痒 & 2 \\
\hline " & 発 & 疹 & 2 \\
\hline$"$ & 湿 & 疹 & 2 \\
\hline 4 & 不 & 眠 & 1 \\
\hline$"$ & \multicolumn{2}{|c|}{ 呼 吸 困 難 } & 1 \\
\hline$"$ & \multicolumn{2}{|l|}{ 腹 } & 1 \\
\hline " & \multicolumn{2}{|c|}{ 変色のある皮闹 } & 1 \\
\hline$"$ & & 鳴 & 1 \\
\hline$"$ & \multicolumn{2}{|c|}{ 扁 桃 肥 大 } & 1 \\
\hline & \multicolumn{2}{|c|}{ そ の 他 } & 2 \\
\hline & 合 計 & & 14 \\
\hline
\end{tabular}

18）神秘湯

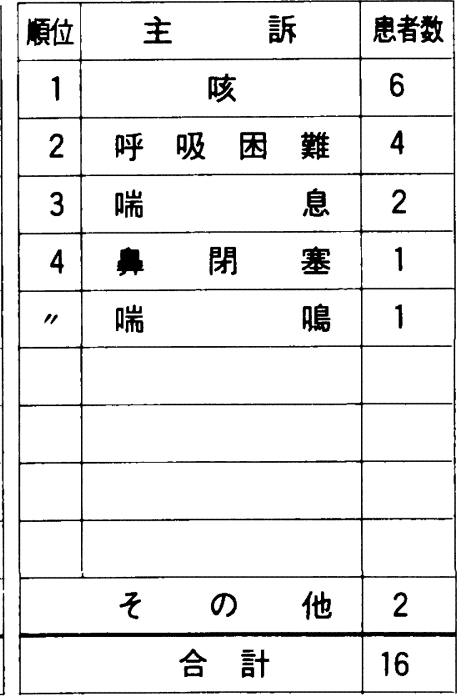


19）抑肝散加陳皮半夏

\begin{tabular}{|c|c|c|c|c|c|}
\hline 醇位 & \multicolumn{4}{|c|}{ 主 } & \multirow{2}{*}{$\frac{\text { 患者 }}{2}$} \\
\hline 1 & & 常 & 運 & 動 & \\
\hline 2 & 精 & 神 & 異 & 常 & 1 \\
\hline " & \multicolumn{4}{|c|}{ 咳 } & 1 \\
\hline " & 麻 & & & 㾝 & 1 \\
\hline " & \multicolumn{4}{|c|}{ 手足のしびれ } & 1 \\
\hline " & \multicolumn{4}{|c|}{ 不 } & 1 \\
\hline " & \multicolumn{3}{|c|}{ 頭 } & 重 & 1 \\
\hline " & \multicolumn{4}{|c|}{ 体 の 振 え } & 1 \\
\hline & & & & & \\
\hline & & & & & \\
\hline & & & & & \\
\hline & & & & & \\
\hline & そ & & D & 他 & 3 \\
\hline & & & 計 & & 12 \\
\hline
\end{tabular}

20）抑肝散

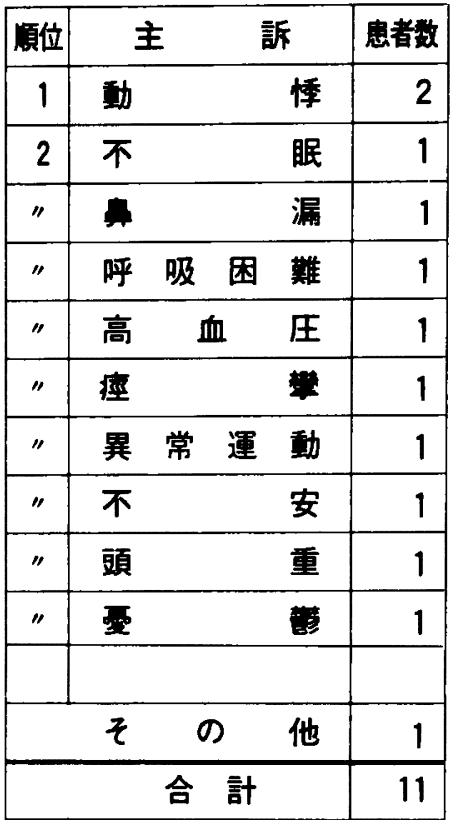

$[5 ， 7), 9) ， 10)$ の急者数 1 人 は省略しその他に入れた。
21）柴陥湯

\begin{tabular}{|c|c|c|c|c|}
\hline 厡位 & 主 & 訴 & & 急者 \\
\hline 1 & 胸 & & 痛 & 3 \\
\hline 2 & \multicolumn{3}{|c|}{ 哇 } & 2 \\
\hline 3 & 咽 & 頭 & 痛 & 1 \\
\hline " & \multicolumn{3}{|c|}{ 咽 頭 異物 感 } & 1 \\
\hline " & \multicolumn{3}{|l|}{ 喘 } & 1 \\
\hline & $z$ & の & 他 & 1 \\
\hline \multicolumn{4}{|c|}{ 合 計 } & 9 \\
\hline
\end{tabular}

22）加味州脾湯

\begin{tabular}{|c|c|c|c|c|}
\hline 硯位 & \multicolumn{3}{|c|}{ 主訴 } & 急者㜔 \\
\hline 1 & \multicolumn{3}{|c|}{ 変色のある皮氘 } & 2 \\
\hline 2 & 月 & 経 異 & 常 & 1 \\
\hline " & 疲 & 労 倦 & 意 & 1 \\
\hline & そ & の & 他 & 2 \\
\hline & & 合 計 & & 6 \\
\hline
\end{tabular}

